\title{
Kepemimpinan Kristen dalam Pluralitas Indonesia
}

\author{
Johannis Siahaya \\ Sekolah Tinggi Agama Kristen Teruna Bhakti, Yogyakarta \\ charistajasmine@gmail.com
}

\begin{abstract}
Leadership is an activity that involves the leaders of where, when, and what he does. In many areas, leadership is a crucial activity advance and retreat of an organization or institution. The same thing happened with the Christian leadership, which is an activity Christian leaders wherever located. In the context of Indonesia's leadership in plural, it takes a complete leader and integrity. A visionary leader, biblical means to have the basics of leadership according to the Bible, which is the word of God which is the handle of a Christian leader.
\end{abstract}

Keywords: biblical, integrity, leadership, visionary

\begin{abstract}
Abstrak: Kepemimpinan merupakan suatu kegiatan yang melibatkan para pemimpin dimana, kapan, dan apa yang dikerjakannya. Dalam berbagai bidang, kepemimpinan adalah suatu kegiatan yang sangat menentukan maju dan mundurnya sebuah organisasi atau lembaga. Hal yang sama juga terjadi dengan kepemimpinan Kristen, yang adalah sebuah kegiatan para pemimpin Kristen dimanapun berada. Dalam konteks kepemimpinan di Indonesia yang pluralis, maka dibutuhkan seorang pemimpin yang lengkap dan berintegritas. Seorang pemimpin yang visoner, alkitabiah artinya memiliki dasar-dasar kepemimpinan yang sesuai dengan Alkitab, yang adalah firman Tuhan yang adalah pegangan seorang pemimpin Kristen.
\end{abstract}

Kata Kunci: alkitabiah, integritas, kepemimpinan, visioner

\section{Pendahuluan}

Yakob Tomatala menulis bahwa: "kepemimpinan adalah suatu seni yang usianya setua umur manusia di bumi." " Hal ini memberikan indikasi bahwa kepemimpinan, jika dianggap sebagai ilmu merupakan ilmu yang paling tua di bumi. Jika dianggap sebagai "sebuah benda," maka benda tersebut adalah benda yang paling tua dan langka di muka bumi ini. Kepemimpinan yang sangat tua itu, dimulai dengan adanya institusi rumah tangga. ${ }^{2}$ Ide ini didukung oleh pendapat Agus Lay bahwa: "Kepemimpinan telah ada sejak manusia hidup berkelompok."3 Dengan demikian, kepemimpinan sudah digumuli dan dipergunakan dalam jangka waktu yang sangat panjang.

\footnotetext{
${ }^{1}$ Yakob Tomatala, Kepemimpinan yang Dinamis (Jakarta: YT Leadership Foundation, 1997), 1.

${ }^{2}$ Ibid.

${ }^{3}$ Agus B. Lay, Manajemen Pelayanan (Jakarta: Lembaga Pelayanan Mahasiswa Indonesia, 1988), 13
} 
Kepemimpinan adalah suatu seni atau kegiatan yang sudah ada sejak dahulu kala. Kepemimpinan pada prinsipnya sama dimana dan kapan saja. John Haggai memberikan pengertian kepemimpinan sebagai:

Suatu tindakan disiplin yang dengan sengaja mempengeruhi orang-orang secara khusus dalam sebuah kelompok untuk bergerak maju kedepan untuk mencapai gol yang bermanfaat secara tetap yang sesuai dengan kebutuhan yang diperlukan dalam kelompok tersebut. ${ }^{4}$

Namun jika berbicara mengenai arti kepemimpinan, maka pengertiannya terdiri dari beberapa aspek yang berbeda. Agus B Lay, mengatakan demi keseragaman maka kepemimpinan itu terbagi menjadi dua bagian, yaitu memimpin dan pemimpin. ${ }^{5}$

Pertama, memimpin. Memimpin adalah usaha mempengaruhi, menggerakan dan mengarahkan orang lain untuk siap melaksanakan seperangkat kegiatan demi mencapai tujuan yang ditetapkan. ${ }^{6}$ Jika demikian, maka kepemimpinan adalah suatu tindakan untuk mempengaruhi dan mengerakan orang lain demi tujuan yang telah ditetapkan. Chris Marantika mengatakan bahwa; kepemimpinan adalah suatu sikap mental dan juga suatu tindakan. ${ }^{7}$ Ini berarti unsur tindakan atau usaha selalu ada di dalam sebuah kepemimpinan. Bahkan kepemimpinan telah mempengaruhi banyak orang dalam berbagai bidang, termasuk didalamnya bidang politik, ekonomi, dan sebagainya. ${ }^{8}$

Kedua, pemimpin. Pemimpin adalah seseorang atau pribadi yang mengetahui tujuannya dengan jelas, serta mampu mempengaruhi, menggerakkan dan mengarahkan orang lain untuk mencapai tujuan yang lebih efektif. ${ }^{9}$ Ini berarti kepemimpinan melibatkan seseorang yang mengerti dengan jelas tujuan dari apa yang dipimpinnya. Dengan demikian apa yang dikatakan Chris Marantika sangatlah tepat bahwa; pemimpin adalah seseorang yang menuntun kegiatan-kegiatan orang lain, namun ia sendiri giat untuk melakukan kegiatan-kegiatan itu. ${ }^{10}$ Jadi tidak hanya mempengaruhi dan menggerakan orang lain, tetapi juga pemimpin itu ikut terlibat di dalam kegiatan itu. Selain keterlibatan secara langsung oleh pemimpin dalam mencapai tujuan, seorang pemimpin juga haruslah berkarakter dan mempunyai kecapan atau kemampuan, serta berkomitmen terhadap kepemimpinan. ${ }^{11}$

Jadi kepemimpinan secara umum terdiri dari dua unsur penting, yaitu; memimpin dan pemimpin; di mana keduanya merupakan bagian yang terintegerasi untuk mencapai sebuah

\footnotetext{
${ }^{4}$ John Haggai. Lead On:Leadership that Endures in a Changing World (Waco, Texas: Word Books, 1986), 4.

${ }^{5}$ Ibid.

${ }^{6}$ Ibid.

${ }^{7}$ Chris Marantika, "Manajemen Kepemimpinan” Diktak Kuliah (Program Pasca Sarjana, STII), 4.

${ }^{8}$ Tomatala, Kepemimpinan yang Dinamis , 9

${ }^{9}$ Lay, Managemen Pelayanan, 29

${ }^{10}$ Marantika, Diktat Kuliah, 5.

${ }^{11}$ Tomatala, Kepemimpinan yang Dinamis, 20.
} 
tujuan yang telah ditetapkan. Keduanya juga merupakan perangkan yang mempengaruhi dan menggerakkan orang lain untuk mencapai tujuan tersebut.

\section{Dasar Alkitab Kepemimpinan Kristen}

\section{Perjanjian Lama}

Kepemimpinan di dalam perjanjian lama sebenarnya sudah dimulai sejak di taman Eden. Pada manusia diciptakan, Adam diperintahkan untuk memerintah dan menguasi segala ciptaan yang lain (Kej. 1:28). Sejak saat itu, Allah bekerja dengan pribadi-pribadi tertentu dan menjadikan mereka menjadi pemimpin bagi kelompok keluarga, kelompok suku bahkan kelompok bangsa. Dalam pembahasan ini, penulis tidak akan membahas semua kepemimpinan dalam perjanjian lama. Dua tokoh yang terkenal akan menjadi rujukan pembahasan ini, seperti Musa dan Nehemia.

\section{Kepemimpinan Musa}

Alkitab dengan gamblang memberikan catatan dan porsi yang cukup bagi prinsip kepemimpinan yang dilakukan Yitro (ayah mertua Musa) kepada Musa. Dalam Keluaran 18:13-27, terdapat beberapa prinsip kepemimpinan yang diberikan kepada Musa. Pertama, Musa harus dapat mengidentifikasikan masalah yang dihadapi (Kej. 18:13-15). Seorang pemimpin yang baik, adalah pemimpin yang dapat memahami semua persoalan yang dihapinya. Bagaimana caranya mengetahui dan mengerti persoalan-persoalan yang dihadapi? Dimulai dengan identifikasi masalah.

Kedua, setelah masalah teridentifikasi, maka mulailah dengan perencanaan. Setelah Musa mengidentifikasi masalah yang dihadap, Jitro memberikan nasehat kepadanya untuk mulai sebuah perencanaa (ayat 19). Lay menulis mengapa orang Kristen perlu membuat perencanaan? Salah satunya adalah orang Kristen ingin hidup teratur. Selanjutnya Engstrom dan Dayton menulis bahwa: "Pada dasarnya kita berencana untuk meningkatkan kemungkinan bahwa apa yang kita percaya harus terjadi, akan terjadi." ${ }^{12}$ Dengan demikian perencanaan merupakan hal yang penting, yang juga ditekankan dalam Alkitab.

Ketiga, Musa diperintahkan oleh Yitro mertuanya untuk menjadi "mentor" (ayat 20). Seorang pemimpin yang baik dan berhasil adalah pemimpin yang mampu menolong orang lain untuk belajar dari dirinya. Juga menolong orang lain untuk lebih menguasai bidangnya dengan mengikuti sebuah pembelajaran.

Keempat, Yitro mendorong musa untuk mengorganisir orang-orang yang cakap untuk membantunya (ayat 20-26). Unsur pengorganisasian merupakan salah satu unsure penting dalam manajemen kepemimpinan. Agus Lay memberikan definisi bagi pengorganisasian sebagai; suatu proses penempatan orang-orang kedalam satu struktur untuk bekerjasama demi mencapai tujuan yang telah ditetapkan. ${ }^{13}$ Dengan demikian apa yang tertuang dalam

\footnotetext{
${ }^{12}$ Ted W. Engstrom dan Edward R. Dayton, Seni Manajemen (Bandung: Yayasan Kalam Hidup,
} 1998). 38.

${ }^{14}$ Lay, Managemen Pelayanan, 11. 
Alkitab tentang pengorganisasian, menjadi prinsip umum yang dipakai di dalam dunia kepemimpinan dan manajemen.

Kelima, setelah keempat prinsip yang sudah dibahas diatas, salah satu prinsip yang sangat menonjol dari semua prinsip diatas adalah "pendelegasian" (ay. 24-26). Musa harus membagi-bagi tanggungjawabnya kepada kelompok seribu, seratus, limapuluh dan kelompok sepuluh. Dengan adanya pendelegasian, maka seorang pemimpin dapat membagiakan bebannya kepada orang lain. Melalui pendelegasian juga, seorang pemimpin dapat mengetahui dan menemukan orang-orang yang berpotensi. Dimana suatu saat orang potensi ini dapat mengambil alih kepemimpinannya.

Prinsip keenam adalah pengendalian. Sebuah program yang sudah direncanakan dan dijalankan sedapat mungkin dikontrol oleh pemimpinnya. Apabila seorang pemimpin tidak melakukan kontrol, maka hampir dapat dipastikan bahwa pelayanan yang diembankan itu akan berjalan kurang efektif. Pengendalian merupakan alat ukur yang baik bagi seorang pemimpin dan organisasi yang dipimpinnya.

Prinsip ketujuh yang dicatat dari kitab Keluaran ini adalah evaluasi. Sebaik apapun seorang pemimpin dan program yang dibuatnya, tidaklah lengkap jika program dan pemimpin itu sendiri mengalami apa yang disebut evaluasi. Evaluasi akan menolong seorang pemimpin dan organisasinya untuk mengerti apa yang menjadi kelebihan dan kekuarangan dari semua pelayanan yang dibuatnya.

Jadi dapat disimpulkan bahwa kepemimpinan Musa berdiri diatas tujuh prinsip yang telah dibahas diatas. Ketujuh prinsip ini merupakan suatu kesatuan yang tidak bisa dipisahkan oleh siapapun. Jika pemimpin Kristen masa kini mempunyai prisnsip kepemimpinan seperti Musa, maka kepemimpinan ini akan sangat diberkati Allah.

\section{Kepemimpinan Nehemia}

Selain Musa yang dipakai sebagai contoh seorang pemimpin dan kepemimpinannya di Perjanjian Lama, orang yang lain yang patut dicontohi adalah Nehemia. Prinsip-prinsip kepemimpinan yang terdapat pada Musa, juga terdapat pada Nehemia. Hanya saja ada beberapa perbedaan. Prinsip pertama yang ada pada Nehemia adalah adanya "visi." Kepemimpinan yang visioner akan dibahas kemudian, hanya saja khusus pada bagian ini akan disinggung sedikit mengenai visi. Seorang pemimpin adalah seorang yang memiliki visi. Tanpa visi, arah kepemimpinannya menjadi tidak beraturan. Nehemia melihat jauh kedepan. Ia berada di tanah pembuangan, tetapi ia bisa merasakan apa yang sedang dirasakan olehy bangsanya Israel di negara asalnya. Visi akan menentukan arah seorang pemimpin untuk melakukan pekerjaan dan pelayanannya.

Visi yang diterima oleh Nehemia bukanlah visi dari manusia, tetapi visi dari Tuhan (1:5-6). George Barna menulis bahwa visi yang dipakai oleh seorang pemimpin Kristen untuk memimpin orang-orang tidak boleh visi yang dibuat sendiri, tetapi visi yang berasal dari Tuhan. ${ }^{14}$ Selanjutnya Barna mengatakan bahwa visi merupakan gambaran mental yang

\footnotetext{
${ }^{14}$ George Barna, Leaders on Leadership (Malang: Gandum Mas, 2002), 55.
} 
jelas mengenai masa depan yang lebih baik, yang disampaikan Tuhan kepada para pemimpinNya. $^{15}$

Jadi prinsip yang dapat dipelajari dan menjadi rujukkan bagi para pemimpin Kristen dalam kepemimpinannya adalah seorang pemimpin harus mempunyai visi. Pemimpin Kristen baik itu pemimpin lembaga Kristen, maupun pemimpin di dalam jemaat haruslah memiliki visi yang datangnya dari Tuhan. Dengan demikian, ada delapan (8) prinsip yang dapat dipelajari dari dua contoh pemimpin dalam Perjanjian Lama.

\section{Prinsip Kepemimpinan dalam Perjanjian Baru}

Setelah memepelajari mengenai prinsip kepemimpinan dalam perjanjian lama. Sekarang akan dipelajari apa yang dikatakan oleh Perjanjian Baru tentang kepemimpinan. Jika berbicara megnenai kepemimpinan dalam perjanjian baru, maka ada dua tokoh besar pernajian baru yang dapat menjadi contoh bagi sebuah kepemimpinan.

\section{Kepemimpinan Yesus}

Yesus adalah Allah sejati dan manusia sejati, sehingga apa saja yang Yesus kerjakan tidak bisa dibandingkan dengan pekerjaan manusia. Namun demikian, pada bagian ini dapatlah dipelajari fokus dari kepemimpinan Yesus. Pertama yang dipelajari dari kepemimpinan Yesus adalah berfokus kepada "individu," Di dalam Injil terdapat banyak contoh, bahkan mendominasi pelayanan Yesus yaitu berorientasi kepada individu atau manusia secara pribadi. Dari semua kitab, pasal dan ayat dalam Injil, Yohanes 21 merupakan perikop yang sangat menonjolkan kepedulian Yesus kepada Indiovidu.

Kedua, kepemimpinan Yesus berfokus kepada tujuan. Yesus mengerti dengan jelas tujuan kedatanganNya kebumi. Yesus juga mengerti bahwa waktunya di bumi sangat terbatas, sehingga Ia perlu mempersiapkan murid-murid untuk meneruskan pelayananNya demi tercapai tujuan yang diberikan kepadaNya. Tujuan utama kedatangan Yesus kebumi adalah mencari dan menyelamatkan yang terhilang (Luk. 19:10). Tujuan itu diteruskan kepada murid-muridNya dengan memberikan amanah dalam Matius 28:19-20, yang merupakan sebuah amanat yang agung.

Ketiga, fokus pelayanan dan kepemimpinan Yesus yang dalam hal ini berpusat kepada kitab Suci. Hal ini dapat dilihat dalam Matius 5:21-48. Semua pernyataan Yesus dikembalikan untuk menyelidiki Alkitab. Yesus tidak pernah melupakan kitab suci dalam membangun pelayanan dan kepemimpinanNya.

Pelajaran yang dapat dipetik bagi kepemimpinan Kristen adalah bahwa fokus itu sangat penting. Manusia, tujuan dan kitab suci merupakan seperangkat sarana yang dapat dipakai oleh seorang pemimpin Kristen untuk mengembangkan kepemimpinannya.

\section{Kepemimpinan Paulus}

Pribadi yang lain dalam Perjanjian Baru yang sangat berpengaruh dalam pelayanan dan kepemimpinan adalah Paulus. Ia sudah menjadi pemimpin sebelum menjadi orang Kristen. Namun pengaruh terbesarnya dalam kepemimpinan terjadi ketika ia memulai pelayanan

\footnotetext{
${ }^{15}$ Ibid.
} 
Kristen. Dari kepemimpinan Paulus ada satu prinsip yang dapat ditarik dari sejumlah besar prinsip pelayanan dan kepemimpinan, yaitu kepemimpinan-contoh.

Sejak Paulus menjadi orang Kristen dan berkecimpung dalam pelayanan, ia menulis sekitar 13 buku atau kitab. Ia juga menulis banyak prinsip dan doktrin dalam setiap kitabnya. Ia juga menasehati begitu banyak orang dan kelompok. Dan kebanyakan dari mereka mengikutinya. Hal yang paling menonjol dan yang menjadi cirri kepemimpinan Paulus adalah memberi teladan atau contoh.

Prinsip ini sangat menarik, karena kepemimpinan Kristen bukanlah kepemimpin "bos," tetapi kepemimpinan yang mengikuti teladan. Kepemimpinan Paulus tidak hanya sebatas retorika belaka. Juga tidak sekedar teoritis yang ditulis dalam setiap surat kirimannya. Namun ia memberikan teladan baik dalam perkataan, perbuatan, tingkahlaku, pelayanan dan termasuk didalamnya kepemimpinannya.

Kesimpulan yang dapat diambil dari dua tokoh Perjanjian Baru ini adalah bahwa kepemimpinan Kristen hendaknya mempunyai focus. Fokus kepada manusi, tujuan dan berfokus kepada kitab suci. Selain itu, kepemimpinan perjanjian baru adalah kepemimpinan yang memberi keteladanan.

\section{Pembahasan}

\section{Kepemimpinan Kristen}

Kepemimpinan Kristen mempunyai prinsip yang sama dengan kepemimpin secara umum. Namun demikian, pada kepemimpinan Kristen terdapat perbedaan yang mendasar, di mana kepemimpinan Kristen didasarkan pada Alkitab. Perbedaannya terletak pada keunikan yang terdapat dalam kepemimpinan Kristen, yakni hakikatnya yang teosentris. Ted Engstrom menulis bahwa; kepemimpinan Kristen ialah kepemimpinan yang dimotivasi oleh kasih dan disediakan khusus untuk melayani. ${ }^{16}$ Jelas di sini bahwa kepemimpinan Kristen bukanlah kepemimpinan "dunia," di mana unsur "bos" terlibat di dalamnya. Tetapi sebaliknya kepemimpinan Kristen diperuntukan untuk "melayani." Hal ini senada dengan apa yang dikatakan oleh Yakob Tomatala bahwa kepemimpinan Kristen juga memiliki konteks pelayanan. ${ }^{17}$ Maksudnya ialah kepemimpinan pada sisi ini lebih menekankan aspek 'melayani', yaitu melayani Allah, melayani gereja dan melayani penginjilan dunia. Ada beberapa pengertian khusus mengenai kepemimpinan Kristen, yang didasari oleh Alkitab.

\section{Kepemimpinan Yang Melayani}

Pertanyaan yang muncul dalam bagian ini adalah mengapa kepemimpinan Kristen itu dihubungkan dengan kepemimpinan yang melayani? Jawabannya sederhana, bahwa kepemimpinan Kristen bukanlah kepemimpinan yang ada pada sebuah perusahan atau pabrik. Kepemimpinan Kristen adalah kepemimpinan kepada umat yang perlu dilayani. Dari pengertian kepemimpinan dan pelayanan saja terdapat kontradiksi. Pemimpin

\footnotetext{
${ }^{16}$ Ted Engstrom dan Edward Dayton, Seni Manajemen Bagi Pemimpin Kristen (Bandung: Yayasan Kalam Hidup, 1998), 20.

${ }^{17}$ Tomatala, Kepemimpinan Yang Dinamis, 43.
} 
berkonotasi "bos," atau "tuan," sedangakan pelayan berkonotasi "hamba," atau "budak." Kepemimpinan Kristen bukan juga berhubungan dengan seseorang yang mempunyai kuasa dan berkuasa. Walaupun pada kenyataannya kepemimpinan selalu berhubungan dengan 'power' ${ }^{18}$. Namun menurut Robert Greenleaf, kedua kata yang menjadi kontradisi dan paradoks ini, dapat dipersatukan dalam kepemimpinan Krisrten sebagai "Kepemimpinan Pelayan" 19

Sebenarnya paradoks ini memang tidak masuk akal. Bagaimana seseorang bisa menjadi pemimpin sekaligus menjadi pelayan (hamba)? Yesus memberikan pengajaran yang menjadi paradoks bagi kebanyakan orang, "Jika seseorang ingin menjadi yang terdahulu, hendaklah ia menjadi yang terakhir dari semuanya dan pelayan dari semuanya" (Mark. 9:30-37). Sebuah prinsip kepemimpinan yang diajarkan oleh Yesus pada bagian ini, di mana yang ingin menjadi terdepan, haruslah menjadi yang terbelakang, dan yang ingin menjadi "pemimpin," haruslah menjadi "hamba." Ini berarti keberhasilan kepemimpinan Kristen tidak terletak pada berapa orang yang mengikutinya, tetapi berapa jumlah orang yang dilayani. Yesus memutarbalikan seratus delapan puluh derajat konsep kepemimpimpinan yang dipikirkan oleh dunia dan juga para muridNya. ${ }^{20}$

Jadi, prinsip kepemimpinan Kristen adalah seseorang yang dengan rendah hati dan rela untuk mengabdi menjadi pelayan atau hamba. Dan jika disejajarkan dengan peinsip kepemimpinan secara umum, maka kepemimpinan Kristen adalah suatu tindakan dan upaya untuk mempengaruhi, menggerakkan dan mengarahkan orang lain untuk mencapai tujuan yang telah ditetapkan dengan disertai campur tangan Allah. Kepemimpinan itu juga disertai sikap mental seorang hamba atau pelayan.

\section{Unsur-unsur Kepemimpinan Kristen}

Dari pengertian kepemimpinan Kristen di atas, maka minimal ada empat unsur utama dalam kepemimpinan Kristen, yaitu: Pertama, kepemimpinan yang berkarakter. Kedua, corak atau gaya kepemimpinan. Ketiga, kepemimpinan yang berorientasi kepada manusia. Dan yang keempat adalah kepemimpinan yang berorientasi kepada tujuan.

\section{Kepemimpinan yang Berkarakter}

Pada dasarnya, para pemimpin masing-masing memiliki "keunikan" dan "individualitas". 21 Selain itu ada juga krakteristik yang membedakan, yang harus dimiliki oleh pemimpin ${ }^{22}$, yakni: Bersemangat, selalu optimis dan mempunyai harapan, dan melihat kesempatan yang ada bagi organisasi yang dipimpinnya; dapat dipercaya, seorang yang jujur dan transparan dalam semua urusan dan hubungannya; berdisiplin, seorang yang dapat memimpin orang lain karena ia dapat menaklukan dirinya sendiri dan telah ditaklukan oleh Tuhan; tegas, seorang yang keputusannya selalu jelas dan cepat; loyal, kepada institusi dan kepada Allah

\footnotetext{
${ }^{18}$ Sanjaya, Kepemimpinan Kristen (Yogyakarta: Kairos Books, 2004), 85.

${ }^{19}$ Robert K Greenleaf, The Power of Servant Leadership (San Francisco: Berrett-Koehler Publishers, 1998), 3.

${ }^{20}$ Sanjaya, Kepemimpinan Kristen, 87.

${ }^{21}$ Marantika, Diktat Kuliah: Managemen Kepemimpinan, 12.

${ }^{22}$ Ibid., 13.
} 
yang memanggilnya; tidak mementingkan diri sendiri, seorang yang melupakan kepentingan pribadinya, yang mementingkan kepentingan kelompok di atas, kepentingan pribadinya.

Sanjaya mengatakan bahwa seorang pemimpin yang berkakter adalah seorang yang mempunyai integritas. ${ }^{23}$ Integritas merupakan unsur yang sangat penting bagi seorang pemimpin, namun juga merupakan unsur yang jarang dimiliki oleh para pemimpin. Alasan yang dikemukan oleh Fred Smith dapat menjadi rujukan, mengapa dibutuhkan seorang pemimpin yang mempunyai integritas.

Memimpin dengan integritas menumbuhkan beberapa pengertian kepada kita bahwa sekarang lembaga gereja sudah hampir sangat tergantung kepada prinsip-prinsip kepemimpinan manusia...Apa yang saya kuatirkan adalah bahwa di dalam gereja mungkin kita akan berusaha melakukan pekerjaan Tuhan dengan cara manusia. ${ }^{24}$

Indikasi seperti ini membuat gereja harus mempunyai seorang pemimpin yang berkarakter baik dan kuat, serta mempunyai integritas. Oleh karena itu, Sanjaya mengutip Waren Bennis, menulis bahwa integritas adalah fondasi untuk membangun rasa percaya. ${ }^{25}$ Rasa percaya disini berhubungan dengan tantangan yang akan dihadapi oleh seorang pemimpin Kristen. Apabila bertemu dengan tantangan moral, seorang yang berintegritas dan berkarakter dapat mengantisipasi dan memprediksi apa yang akan dihadapi.

\section{Corak atau Gaya Kepemimpinan}

Unsur kedua yang dapat dilihat dari seorang pemimpin Kristen adalah Gaya kepemimpinanya. Gaya kepemimpinan merupakan unsure yang penting, karena mencerminkan kepribadian seorang pemimpin. Ada beberapa gaya yang dipakai dalam sebuah kepemimpinan. Ted Engstrom memberikan beberapa gaya yang dipakai dalam tulisan-tulisannya, yakni: gaya laissez faire, demokratif-partisitif, benevolen-autokratif, dan autokratif-birokratif. $^{26}$

Gaya laissez faire memberikan kepada seorang pemimpin sentuhan yang sangat minimum, sebaliknya memberikan kebebasan kepada kelompok untuk mengambil keputusan. ${ }^{27}$ Gaya seperti ini barangkali kurang cocok bagi seorang pemimpin yang harus memimpin. Bahkan gaya semacam ini oleh Bennie Goodwin disebut gaya kepemimpinan "Aku." 28 Laissez faire diperuntukan bagi seorang pemimpin yang juga adalah "pemilik" dari organisasi itu. Gaya ini dapat disejajarkan dengan gaya kepemimpinan "geradi manajemen kering”, yang oleh Lay disebut sebagai: "Gaya yang sangat kecil perhatiannya baik terhadap manusia. Gaya ini hanya sekedar menyampaikan apa yang dikehendaki oleh

\footnotetext{
${ }^{23}$ Sanjaya, Kepemimpinan Kristen, 62.

${ }^{24}$ Fred Smith, Memimpin dengan Ingritas (Jakarta: Yayasan Pekabaran Injil Imanuel, 2002), 11.

${ }^{25}$ Sanjaya, Kepemimpinan Kristen, 62.

${ }^{26}$ Ted W. Engstrom, The Making of a Christian Leader (Grand Rapids: Zondervan Publishing House,

${ }^{27}$ Ibid., 71.

${ }^{28}$ Bennie E. Goodwin, Kepemimpinan yang Efektif (Jakarta: Perkantas, 2000), 15.
} 1976), 71-73 
organisasi kepada orang-orang yang menjadi anggota organisasi itu. Tidak ada usaha yang sungguh-sungguh dalam usaha untuk mencapai tujuan yang telah ditetapkan."29

Gaya ini tidak terlalu cocok bagi kepemimpinan Kristen, dan sedapat mungkin dihindari. Apalagi jika gaya ini dipakai oleh seorang pemimpin jemaat. Alasannya sangat sederhana, karena pemimpin jemaat bukanlah 'bos,' tetapi pemimpin-pelayan atau hamba.

Berikutnya adalah gaya Demokrasi-Partisipasif, di mana pemakaian gaya ini relatif baru dalam perkembangan sejarah dunia, khususnya dalam bidang kepemimpinan. Jika pada gaya laissez faire, kepemimpinan dikontrol oleh satu orang saja, atau elit yang memegang kekuasaan, maka pada gaya demokrasi pengambilan keputusan dilakukan dengan melibatkan orang-orang yang ada di dalam kelompok itu. Gaya ini menciptakan rasa memiliki sasaran dan tujuan secara bersama-sama. ${ }^{30}$ Pemimpin sangat menghargai bawahannya dalam segala hal. Pemimpin berusaha untuk memanfaatkan gagasan-gagasan bawahan secara kreatif, serta mengikut sertakan bawahan dalam perencanaan, evaluasi dan pengambilan keputusan. Gaya kepemimpinan ini cocok bagi kepemimpinan Kristen dan kepemimpinan di dalam jemaat. Hal yang perlu diperhatikan adalah situasi dan kondisi lingkungan. ${ }^{31}$

Gaya Benovalent - Autokratif merupakan gaya seperti seorang ayah dengan anaknya, di mana anak akan melakukan apa saja yang diperintahkan oleh ayahnya. Gaya ini juga sering disebut dengan gaya "paternalistic." "32 Pada bagian ini adanya ketergantungan kepada yang berwenang atau yang memegang kekuasaan. Ada anggapan bahwa orangorang yang dipimpin tidak akan melakukan apa-apa, jika tidak diperintahkan. Sebenarnya gaya ini tidak mendorong adanya pembaharuan. Pemimpin merasa dirinya sangat dibutuhkan dan diperlukan. Sehingga keputusannya dapat dibuat dengan cepat, tanpa perlu pertimbangan orang lain. Gaya ini seharusnya tidak ditiru oleh para pemimpin Kristen dan pemimpin jemaat. Dengan kata lain, gaya ini tidak cocok bagi kepemimpinan Kristen.

Gaya Otokrasi - Birokrasi merupakan suatu gaya yang ditandai dengan keterikatan secara terus menerus kepada aturan-aturan organisasi. Penganut paham ini percaya bahwa kesulitan-kesulitan akan dapat diatasi bila masing-masing orang yang ada di dalamnya mengikuti aturan-aturan yang telah ada. ${ }^{33}$ Kebanyakan organisasi dan pemimpin yang memakai gaya ini adalah organisasi pemerintahan, organisasi industri dan organisasi Kristen. Di dalam kepemimpinan bergaya birokrasi ini sering memakai jalan mufakat dan kompromi sebagai jalan tengah bagi pengambilan keputusan. Karena, sejatinya seorang pemimpin juga harus mampu mengatasi konflik yang terjadi di bawahnya. ${ }^{34}$ Gaya ini juga cocok bagi kepemimpinan Kristen dan kepemimpinan jemaat.

\footnotetext{
${ }^{29}$ Lay, Managemen Pelayanan, 38.

${ }^{30}$ Engstrom dan Dayton, Seni Manejemen bagi Kepemimpinan Kristen. 24.

${ }^{31}$ Lay, Managemen Pelayanan, 43.

${ }^{32}$ Engstrom, The Making of a Christian Leader The Making, 73.

${ }^{33}$ Engstrom dan Dayton, Seni Manejemen bagi Kepemimpinan Kristen. 23.

${ }^{34}$ Maidiantius Tanyid, "Kualitas Pemimpin Sebagai Pendidik Dalam Menghadapi Konflik," BIA'. Jurnal Teologi dan Pendidikan Kristen Kontekstual 1, no. 1 (2018): 124-137, www.jurnalbia.com/index.php/bia.
} 
Dari semua gaya yang diungkapkan diatas, sebenarnya tidak ada gaya yang sangat tepat dipakai dalam kepemimpinan Kristen. Masing-masing gaya mempunyai keunggulan dan kelemahannya sendiri-sendiri. Namun demikian ada gaya yang dapat dipakai dalam kepemimpinan Kristen dan kepemimpinan di dalam gereja. Gaya demokrasi dan Birokrasi dapat dikombinasikan dan dipakai oleh setiap pemimpin Kristen. Kekristenan membutuhkan birokrasi, tetapi yang demokrasi. Termasuk di dalamnya gaya kepemimpinan, baik bagi orang yang dipimpin maupun bagi para pemimpinnya.

\section{Kepemimpinan yang Berorientasi kepada Manusia}

Pada dasarnya dalam sebuah organisasi, termasuk organisasi Kristen terdapat dua kelompok manusia. Kedua kelompok tersebut adalah kelompok pimpinan dan kelompok yang dipimpin. Kelompok pemimpin dalam dunia sekuler dapat dibagi menjadi beberapa bagian yang disebut "eselon." Dalam kepemimpinan Kristenpun dibagi menjadi bagianbagian tersebut, sesuai dengan proporsi yang ada. Sedangkan kelompok yang dipimpin adalah kelompok yang selalu mengikuti apa yang diingini oleh orang yang memimpinnya.

Pada pembahasan dasar alkitabiah tentang prinsip kepemimpinan, telah diberi contoh dari perjanjian baru. Yesus yang menjadi tokoh sentral dalam pembahasan itu memberikan contoh bagaimana fokus dari kepemimpinan adalah berorientasi kepada manusia. Sebagai seorang pemimpin Yesus sangat mendahulukan orang yang dipimpinNya. Leroy Eims menulis bahwa salah satu sasaran utama dari para pemimpin Kristen adalah memperhatikan kebutuhan orang yang dipimpinnya. ${ }^{35}$ Sudah tentu kebutuhan utama dalam kepemimpinan Kristiani adalah kebutuhan rohani.

Orientasi kepada manusia sangatlah penting, karena kepemimpinan tanpa melibatkan manusia adalah kosong belaka. Salah satu keselahan terbesar yang dilakukan oleh para pemimpin adalah mendahulukan hal-hal administrasi dari pada manusia. ${ }^{36}$ Kepemimpinan dan pemimpin dapat berhasil menjalankan program, namun perhatian dan kepeduliaan akan orang-orang yang dipimpin sangatlah rendah. Selanjutnya Finzel menulis:

Kelompok yang saya pimpin sama sekali tidak mengkritik cara saya memimpin dan melaksanakan tugas. Malah mereka semua sependapat bahwa hasil kerja saya sempurna. Saya tidak pernah gagal melaksanakan tugas saya. Namun saya gagal dalam aspek "sikap." Masalahnya adalah bahwa mereka menginginkan perhatian saya, dan saya selalu saja terlalu sibuk untuk memberikannya. ${ }^{37}$

Di sini dapat dilihat betapa pentingnya perhatian dan kepedulian seorang pemimpin kepada orang yang dipimpinnya. Hal ini melebihi apa saja yang berhubungan dengan kepemimpinan. Dengan kata lain kepemimpinan yang berorientasi kepada manusi tidak bisa dikesampingkan begitu saja. Bahkan dapat dikatakan bahwa orientasi kepada manusia ini sangat memegang peran penting dalam kepemimpinan.

\footnotetext{
${ }^{35}$ Leroy Eims, Be the Leader (Batam: Gospel Press, 2001), 233.

${ }^{36}$ Hans Finzel, Sepuluh Besar Kesalahan yang Dibuat Para Pemimpin (Batam: Interaksara, 2002), 37.

${ }^{37}$ Ibid., 43.
} 


\section{Kepemimpinan yang Berorientasi kepada Tujuan}

Selain orientasi kepada manusia, salah satu penunjang keberhasilan dari sebuah kepemimpinan adalah berorientasi kepada tujuan. Seorang pemimpin yang berorientasi kepada tujuan, menunjukkan bahwa pemimpin itu megnerti dengan benar arah dari sebuah organisasi atau sebuah kepemimpinan yang dipimpinnya. Lingenfelter menulis bahwa misionari, pendeta dan kaum awam yang berorientasi kepada tujuan adalah orang-orang yang sangat memperhatikan dan bertanggungjawab bagi pekerjaan administrasi. ${ }^{38}$

Hal ini berarti para pemimpin yang berorientasi keapda tujuan sangat memperhatikan hal-hal yang berhubungan dengan tertib administrasi. Penjadwalan dan peraturan-peraturan yang dibuat dengan rapi, kemudian dengan disiplin yang tinggi mengikuti semua aturan dan jadwal yang telah ditentukan. Tugas-tugas administrasi seperti ini memang sering dipegang dan dikerjakan oleh para pemimipin. Seperti apa yang ditulis oleh Tomatala bahwa dalam kaitan dengan seluruh aspek kepemimpinan, seorang pemimpin tertinggi dalam organisasi dapat berfungsi sebagai pemimpin administrasi tertinggi. ${ }^{39}$

Tugas dan tanggungjawab administrasi itu sendiri bertitik tolak pada hal-hal teknik, strategi dan taktis dari sebuah kepemimpinan. Ini berarti seorang pemimpin harus menguasai tidak hanya gaya kepemimpinan, tetapi juga semua hal yang berhubungan dengan teknik kepemimpinan. Kemudian juga harus mempunyai strategi yang tepat untuk memimpin, serta harus taktis atau cekatan dalam mengatur dan memempin orang lain.

\section{Kepemimpinan Visioner}

Amsal 29:18 mengatakan: "Bila tidak ada wahyu, menjadi liarlah rakyat." Kata-kata yang singkat tetapi mempunyai makna yang sangat mendalam. Secara implisit, penulis Amsal ingin katakan bangsa atau manusia akan menjadi liar, jika tidak memiliki arah. Dalam terjemahan bahasa Inggris kata wahyu, dipakai kata "visi." Where there is no vision, the people perish. Pada bagian ini dibahas mengenai; pengertian visi. Kedua, pemimpinan visioner adalah seorang yang dipanggil Allah. Ketiga, pemimpin yang visioner adalah seorang yang mempunyai integritas. Keempat, pemimpin yang visioner adalah seorang manejer atau seseorang yang memakai prinsip-prinsip manajemen dalam kepemimpinannya. Kelima, seorang pemimpin yang visioner adalah seorang yang terlibat dalam misi memenangkan jiwa bagi kerajaan Allah.

Visi diberikan kepada seorang pemimpin. Jika pemimpin itu telah memiliki visi, maka visi itu akan ditransfer kepada orang-orang yang mengikutinya. Visi itu sendiri tidak berasal dari pemimpin tersebut, tetapi visi berasal dari Tuhan. Barna menulis bahwa visi sejati datangnya dari Tuhan. ${ }^{40}$ Selanjutnya Barna katakana bahwa jika kita secara pribadi memunculkan visi tentang masa depan, visi kita bisa keliru, kurang dan terbatas, karena visi Tuhanlah yang sempurna dalam segala hal. ${ }^{41}$

\footnotetext{
${ }^{38}$ Sherwood G Lingenfelter dan Mavin K Mayers, Ministering Cross Culturally (Grand Rapids: Baker Book House, 2002), 84.

${ }^{39}$ Tomatala, Kepemimpinan yang Dinamis, 161.

${ }^{40}$ Brame, Leaders on Leadership, 56.

${ }^{41}$ Ibid.
} 
Visi adalah suatu gambaran yang terpampang dimata hati anda mengenai bagaimana sesuatu dapat atau harus terjadi dimasa yang akan datang. ${ }^{42}$ Ini berarti visi ditujukkan kepada masing-masing pemimpin. Visi tidak diberikan secara kolektif, tetapi diberikan kepada pribadi-pribadi yang terlibat dengan gerakan pelayanan dari Allah. Selanjutnya Barna menulis bahwa: "Vision for ministry is a reflection of what God wants to accomplish through you to build His Kingdom". 43 Ini berarti visi memang diberikan kepada seseorang secara pribadi, sesuai dengan apa yang Allah inginkan bagi pribadi-pribadi tersebut.

Dalam bagian yang lain Dale Galloway menulis bahwa visi adalah sebuah kemampuan atau karunia pemberian Allah untuk melihat sesuatu yang sebenarnya tidak realita. $^{44}$ Ini berarti seorang pemimpin yang menerima visi, adalah pemimpin yang mempunyai kemampuan khusus untuk melihat sesuatu yang pada dasarnya belum terjadi, bahkan tidak masuk akal. Visi bagi seseorang bersifat eksklusif dan superior, karena di dalamnya melibatkan Allah. ${ }^{45}$

Jadi, seorang pemimpin Kristen adalah orang yang dipilih Allah secara khusus untuk melayaniNya. Pemimpin Kristen juga harus mempunyai penglihatan atau visi yang jauh kedepan. Melihat akan hal-hal yang belum terjadi, serta visi itu berasal dari Allah bukan dari dirinya sendiri.

\section{Pemimpin Visioner sebagai Panggilan Allah}

Seorang pemimpin yang visioner adalah seorang yang seharusnya mempunyai atau menerima panggilan khusus dari Allah. Senjaya menulis bahwa ketika Allah berkenan membangkitkan seorang pemimpin, maka Allah akan memberikan sebuah panggilan. ${ }^{46}$ Kepemimpinan Kristen bukanlah ambisi pribadi, bukan juga keunggulan dan kemampuan pribadi seseorang. Sikap ketergantungan akan campur tangan Allah haruslah lebih besar bagi seorang pemimpin Kristen. Lebih lanjut seperti yang ditulis oleh Tomatala, mengutip Robert Clinton bahwa pemimpin Kristen adalah seorang yang telah dipanggil Allah sebagai pemimpin. ${ }^{47}$

Allah memanggil seseorang menjadi pemimpin dengan cara yang berbeda-beda dan beragam. Kadangkala Allah memakai cara yang sederhana seperti ia memanggil Nehemia untuk menjadi pemimpin bagi bangsanya. Tetapi kadang Allah memakai cara yang sulit dan sukar dimengerti, seperti panggilan Musa, yang harus melalui semak belukar yang terbakar. Jadi tidak ada alas an bagi seorang pemimpin Kristen untuk mengeluh bahwa, ia tidak dipanggil seperti orang lain.

Juga tidak dapat menajadi alasan bahwa, panggilan yang diberikan Allah kepadanya tidak melalui tanda-tanda ajaib. Jika Allah telah memanggil seseorang, maka Allah mempunyai maksud tertentu dengan orang terbut termasuk di dalamnya para pemimpin

\footnotetext{
${ }^{42}$ George Barna, The Power of Vision (Ventura, CA: Regal Books, 1992), 29.

${ }^{43}$ Ibid.

${ }^{44}$ Dale Galloway, Leading with Vision (Kansas City: Beacon Hill Press, 1993), 13.

${ }^{45}$ Senjaya, Kepemimpinan Kristen, 38.

${ }^{46}$ Ibid., 45.

${ }^{47}$ Tomatala, Kepemimpinan yang Dinamis, 45.
} 
Kristen. Persoalannya adalah mengapa Allah memanggil para pemimpin Kristen? Chris Marantika mengatakan:

Allah dalam menjalankan programnya telah menyentuh dan memanggil pribadipribadi tertentu, dan mereka secara khusus bagi perkembangan gerejaNya. Diantara mereka ada yang cakap, istimewa dan berbakat, tetapi ada juga yang kurang cakap, sederhana dan tidak bebakat.Namun Allah memilih mereka dari antara umatNya untuk mengembangkan pekerjaanNya. Mereka bukanlah orang-orang yang lebih tinggi di dalam gereja, tetpi bukan pula orang-orang yang diluar gereja. Mereka adalah orang-orang dari dan di dalam gereja. ${ }^{48}$

Seperti yang sudah dibahas dibagian sebelumnya bahwa Allah mempunyai cara tersendiri untuk memanggil orang-orang yang akan menjadi pemimpin, seperti Musa dan Nehemia. Dalam sejarah perjalanan Alkitab, dapat dibaca dan diamati bahwa memang Allah memanggil pemimpin dalm pribadi-pribadi tertentu. Ada dari anatara mereka dating dari kalangan orang-orang terpelajar dan mempunyai kedudukan yang tinggi, tetapi ada dari antara mereka yang berasal dari kalangan tidak terpelajar dan dari golongan yang rendah. Beberapa contoh yang patut dikemukakan disini adalah mereka yang dipanggil sebagai pemimpin dalam Perjanjian Baru.

\section{Kepemimpinan Visioner Memakai Fungsi-fungsi Manajemen}

Salah satu tugas dan tanggungjawab seorang pemimpin yang mempunyai visi adalah sanggup memakai fungsi-fungsi manajemen yang ada. Seringkali manajemen dianggap sebagai sesuatu yang "duniawi," sedangakan pelayanan gereja adalah bersifat rohani. Sebenarnya di dalam beberapa bagian Alkitab telah menjelaskan, bahkan memberikan contoh tentang tokoh-tokoh yang menerapkan "manajemen pelayanan." Sebut saja Yusuf, Musa, Nehemiah dan para rasul yang telah menerapkan prinsip-prinsip manejemen dalam pelayanan mereka.

Ini menunjukkan bahwa manejemen tidaklah bertentangan dengan hal-hal rohani. Manajemen itu sendiri bukanlah hal duniawi seperti yang diperkirakan sebelumnya. Fungsi-fungsi manejemen haruslah dikuasai oleh seorang pemimpin yang mempunyai visi. Pemimpin yang Memulai Pelayanan dengan Perencanaan. Yakob Tomatala memberi-kan definisi perencanaan sebagai: Upaya yang merangkum seperangkat kegiatan yang dilakukan berkenan dengan usaha untuk mencapai tujuan. ${ }^{49}$ Dalam terminologi yang lain, perencanaan berarti menetapkan terlebih dahulu seperangkat kegiatan. Seorang pemimpin yang visioner adalah pemimpin yang dalam memulai pelayanannya dengan terlebih dahulu menetapkan apa yang akan dikerjakan. Perencanaan ini merupakan kompas dan peta yang akan menuntun para pemimpin dan organisasi yang dipimpinnya berjalan dengan baik. Nehemiah adalah tokoh Alkitab yang memulai pekrjaannya dengn membuat perencanaan.

Dalam pasal 1-6 kitab Nehemiah dapatlah dipelajari prinsip-prinsip perencanaan. Pertanyaan yang muncul adalah mengapa seorang pemimpin Kristen harus membuat perencanaan? Jawaban yang masuk akal adalah pertama, karena manusia ingin hidup

\footnotetext{
${ }^{48}$ Chirs Marantika, Theologia Pertumbuhan Gerejaa: Materi kelas teologi:Pertumbuhan Gereja, Program D.Min, (Yogyakarta: STII, 2003), 37.

${ }^{49}$ Tomatala, Kepemimpinan Yang Dinamis, 147.
} 
teratur(1 Kor. 14:33, 40). Sejak Allah menciptakan dunia dan isinya, semua ciptaan itu direncakan dengan baik. Ada unsur keteraturan di dalam penciptaan manusia dan alam seisinya. Kedua, Kristus sendiri mengutamakan perencanaan. Pada waktu memulai pelaynanNya, Kristus tidak langsung melayani. Ia memerlukan merencanakan para "pendamping"Nya, siapa-siapa yang perlu terlibat, dari daerah dan latar belakang apa. Sesudah itu, murid-murid yang direkrutNya tidak langsung melayani, mereka harus mengikuti pelatihan selama tiga tahun bersamaNya. Dikemudian hari murid-mrid ini menjadi orang yang sangat berhasil dalam pelayanan. Hal ini disebabkan adanya perencanaan yang baik dari pemimpin.

Pemimpimpin yang memulai pelayanan dengan membuat Program. Salah satu unsur penting dalam kepemimpinan atau sering disebut dengan manajemen kepemimpinan adalah adanya program yang dibuat. Membuat program berarti memenuhi pertanyaan yang dikemukakan: Bagaimana menetapkan langkah-langkah yang perlu diambil dalam rangka usaha untuk mencapai tujuan yang telah ditetapkan. Merencanakan sesuatu tanpa membuat program yang terpadu, sehingga tujuan yang ditetapkan dipenuhi adalah sia-sia. Tomatala mengatakan:

Membuat program pencapaian target yang menyangkut seluruh bahagian dari perencanaan strategis mengenai langkah-langkah atau tugas-tugas yang akan dilakukan. Termasuk semua hal yang perlu dikerjakan yang dilakukan langkah lepas lankah kearah pencapaian sasaran atau tujuan yang telah direncanakan dalam upaya kerja suatu organisasi. ${ }^{50}$

Dengan demikian, program merupakan salah satu bagian yang sangat penting dari sebuah proses kepemimpinan, termasuk di dalamnya kepemimpinan Kristen.

\section{Peranan Pendelegasian dalam Kepemimpinan}

Salah satu factor kepemimpinan yang harus diperhatikan oleh para pemimpin adalah pendelegasian. Ada yang mengatakan bahwa "sharing is delegation"51 Sedangakan Myron Rush mengatakan bahwa delegasi adalah: "Penyerahan kekuasaan, kewajiban dan tanggungjawab dari orang atau kelompok yang lain. Pada umumnya, ia merupakan penyerahan kekuasaan dari tingkat organisasi yang lebih tinggi dalam organisasi ke tingkat yang lebih rendah." 52 Dengan demikian, pendelegasian merupakan suatu tindakan mempercayakan tugas dan kewenangan, serta tanggungjawab, dari seorang pemimpin kepada orang yang dipimpin.

Alkitab sendiri memberikan informasi tentang pentingnya suatu delegasi. Keluaran 18:13-26, merupakan contoh kasus pendelegasian yang sangat berharga bagi para pemimpin. Musa adalah seorang pemimpin yang diurapi Allah dengan luar biasa. Karakter dan kepribadiannya sebagai seorang pemimpin tidak diragukan lagi. Namun demikian, dalam hal kepemimpinan Musa diperhadapkan dengan banyaknya pekerjaan yang tidak dapat diselesaikan. Yitro, adalah seorang penolong yang memberikan formula

\footnotetext{
${ }^{50}$ Tomatala, Kepemimpinan yang Dinamis, 149.

${ }^{51}$ Ibid. 195

${ }^{52}$ Myron Rush, Manajemen menurut Pandangan Alkitab, (Malang: Gandum Mas, 2002), 132
} 
pendelegasian kepada Musa. Rush mengatakan bahwa pendelegasian memberikan beberapa keuntungan. ${ }^{53}$ Pertama, delegasi meringankan pekerjaan manajer. Kedua, meningkatkan produktivitas. Ketiga, melahirkan pemimpin-pemimpin baru. Keempat, memberikan banyak waktu kepada pemimpin Kristen untuk mendewasakan kehidupan roahaninya sendiri. Kelima, delegasi merangsang kreativitas karyawan. Keenam, delegasi menunjukkan kepercayaan dan keyakinan pada kemampuan karyawan. Dan ketujuh, delegasi membangkitkan motivasi dan komitmen pada organisasi.

\section{Peranan Pemimimpin dan Evaluasi}

Selain unsur dan factor kepemimpinan yang sudah dibicarakan diatas, salah satu unsure yang tidak dapat dianggap sepele adalah evaluasi. Evaluasi bagi seorang pemimpin adalah hal penting, agar pemimpin itu dapat mengetahui sejauh mana program dan pola kepemimpinan yang sudah dilakukannya. Rush mengatakan dengan evaluasi, maka dapat mengetahui kesalahan yang dapat diperbaiki sesuai dengan kebutuhan. ${ }^{54}$ Dengan evaluasi, seorang pemimpin akan mengerti hasil kerja dan pelayanan yang telah dilakukan.

\section{Kesimpulan}

Kesimpulan dalam pembahasan ini adalah:

Pertama, para Pemimpin Gereja pada masa kini perlu untuk kembali kepada Alkitab yang menjadi kajian utama bagi misi lintas budaya. Hal ini penting, karena pelayanan misi lintas budaya bukanlah sebuah pelaynan sampingan yang dimasukan untuk memenuhi program gereja yang sudah ada. Alasannya karena misi lintas budaya merupakan program Allah sejak semula untuk mencari dan menyelamatkan yang sesat. Hal ini dibuktikan dengan Allah mengirim anakNya satu-satunya, yakni Yesus Kristus untuk detang ke dunia, mati dan menjadi penebus dosa manusia.

Kedua, para pemimpin gereja yang visioner perlu untuk mengkaji ulang apa motiv dari panggilannya untuk melayni gereja. Apakah ada visi yang didapat dan dipunyi oleh pemimpin gereja masa kini. Visi sangatlah penting bagi seorang pemimpin gereja, karena tanpa visi, maka liarlah suatu bangsa (Amsal 29: 18 ). Visi bagaikan pelita ditengah kegelapan, seorang pemimpin yang berjalan tanpa visi, seperti berjalan di tengah-tengah kegelapan. Untuk itulah para pemimpin gereja harus mampu memahami dan menerjemahkan visi yang telah diberikan Allah kepada mereka.

Ketiga, pemimpin Kristen haruslah seorang yang mempunyai kemampuan manejerial yang baik. Para pemimpin gereja perlu belajar secara pribadi dari Yesus, yang dalam melakukan pelayananNya sangat rapi. Perencanaan yang rapi, organisasi yang rapi(memilih dua belas murid), mampu menjalankan program dengan baik. Tidak kuatir untuk memberikan pendelegasian kepada orang lain untuk melakukan pekerjaannya.

Keempat, pemimpin yang visioner seharusnya seseorang yang paham benar tentang rencana Allah dan misiNya. Kelemahan terbesar yang dialami oleh para pemipin gereja yang menjadi sampel penelitian adalah kurangnya pemahaman yang benar tentang apa

\footnotetext{
${ }^{53}$ Ibid.134-137.

${ }^{54}$ Ibid, 182
} 
yang dimaksudkan dengan misi lintas budaya. Misi merupakan hal yang sangat penting dan urgen. Penting, karena misi ini untuk mencari dan menyelamatkan yang hilang. Urgen, karena waktunya sangat terbatas dan situasi dan kondisi dapat berubah sewaktu-waktu. Oleh karena itu, pemimpin Kristen harus paham benar tentang misi Allah ini, termasuk di dalamnya misi lintas budaya.

Akhirnya, pemimpin yang visioner adalah seorang pemimpin yang mampu menjalankan rencana dan misi Allah dengan baik dan benar. Seorang yang mampun membawa jiwa-jiwa yang tersesat untuk kembali kepada Allah. Seorang yang efektif dalam pelayanan, dan yang kreatif dalam menyusun program bagi menjangkau dunia dan isinya untuk diserahkan kembali kepada sang Khalik, Allah, di dalam Yesus Kristus.

\section{Referensi}

Armstrong, Philip E. dan Ed. Committee. “Evangelical Missions.” Quartely. 1967.

Barna, George. Depower of Vission. California : Regal Books.1992

Blanchard, Ken ; Bill Hybels and Phil Hodges. Leadhership by the Book. New

York: Water Book Press. 1999.

Brougham, David Royal. Merencanakan Misi Lewat Gereja-Gereja Asia. Malang:

Gandum Mas. t.t.

Carson, D. A. and John D. Woodbridge, Peny. God and Culture. Surabaya: Momentum. 2002.

Covey, Stephen R. Pinciple- Centerd Leadhership.London : Simon \& Schuster. 1988.

Covey, Stephen R. The 7 Habbits of Highly Effective People. Jakarta L: Bina Rupa Aksara. 1997.

Engstrom, Ted W., The Making Cristian Leader. Grand Rapids : Pyrane Books. 1976.

Finzel, Hans. Sepuluh Besar Kesalahan yang Dibuat Para Pemimpin. Batam: Interaksara. 2002.

Galloway, Dale\& Warren Bird. On Purpuse Leadership. Jakarta: Harvest Publication House. 1987.

Galloway, Dale. Leading in Times of Change. Kansas City: Beacon Hill Press.2001.

Galloway, Dale. Leading with Vision (Compilation). Kansas City: Beacon Hill Press. 1999.

Galloway, Dale. Making Church Relevant. Kansas City. Beacon Hill Press. 1999.

Gilliand, Dean S, Peny. The Word Among Us. Dallas : Word Publishing.1989.

Greenleaf, Robert K. The Power of Servant Leadhership. San Fransisco: Berrett-Koehler Publ. 1998.

Gulo, W. Metodologi Penelitian. Jakarta: Grasindo.2002.

Haggai, John. Lead On. Waco : Word Books.1986

Hocking, David. Rahasia Keberhasilan Seorang Pemimpin. Yogyakarta: Andi Offset.1994. Hybells, Bill. Courages Leadership. Batam: Gospel Press.2004.

Ingersol, Westracy Stan. Here We Stand. Kansas City: Beacon Hill Press. 1999

Kane, J. Herbert. Understanding Christian Mission. Grand Rapids: Baker Book House.1982.

Kane, J. Herbert. A Concise History of the Cristian Mission. Grand Rapids: Baker Books.1982.

Lay, Agus B. Manajemen Pelayanan. Lembaga Pelayanan Mahasisiwa Indonesia.1988.

Tanyid, Maidiantius. "Kualitas Pemimpin Sebagai Pendidik Dalam Menghadapi Konflik." BIA': Jurnal Teologi dan Pendidikan Kristen Kontekstual 1, no. 1 (2018): 124-137. www.jurnalbia.com/index.php/bia. 